Acta vet. scand. 1988, 29, 159-164.

From the Norwegian College of Veterinary Medicine, and the National Veterinary Institute, Oslo, Norway.

\title{
Seasonal Variation of Selenium Status of Norwegian Dairy Cows and Effects of Selenium Supplementation
}

\author{
By Erik Ropstad, Olav Østerås, Gunnar Øvernes and Arne Frøslie
}

\begin{abstract}
Ropstad, E., O. Østerås, G. Øvernes and A. Frøslie: Seasonal variation of selenium status of Norwegian dairy cows and effects of selenium supplementation. Acta vet. scand. 1988, 29, 159-164. - Blood selenium levels were found to fluctuate throughout the year, being highest during the indoor season when the greatest amounts of compound concentrates were fed. From October to January the average blood selenium levels increased from $0.10 \mu \mathrm{g} / \mathrm{ml}$ to $0.18 \mu \mathrm{g} / \mathrm{ml}$ (15 cows). Subcutaneous injections of barium selenate ( $500 \mathrm{mg}$ selenium) increased the blood selenium levels significantly. The treated group ( 15 cows) reached average levels of about $0.21 \mu \mathrm{g} / \mathrm{ml}$ blood during the indoor season.

The effect of oral supplementation of sodium selenite (for 2 months) on the levels of plasma selenium, blood selenium and glutathione peroxidase activity was investigated. Plasma selenium was found to give an immediate reflection of the daily selenium intake. Maximum activity of glutathione peroxidase was reached 1 month after the end of the supplementation period.

It is concluded that if selenium enriched concentrates are used in a normal feeding regimen, further supplementation with selenium does not seem to be necessary.

sodium selenite; barium selenate; glutathione peroxidase; selenium deficiency.
\end{abstract}

\section{Introduction}

As soils in Norway are generally deficient in selenium, selenium deficiency disorders will appear in livestock unless selenium is provided through sources other than homegrown fodder. Compound concentrates are enriched with selenium at a rate of 0.2 $\mathrm{mg} / \mathrm{kg}$, and it is assumed that animals which are fed high proportions of concentrates, will have a satisfactory selenium intake. Under Norwegian conditions, dairy cattle receive concentrates up to about $50 \%$ of the total dry matter intake. During the dry period, however, the amount of concentrates given is drastically reduced. It is therefore possible that dairy cows, during certain periods of the year, and young grazing cattle, nevertheless have undesirably low blood selenium levels. The purpose of the present investigation was to study, (1) seasonal variations in selenium status of dairy cattle, (2) the effects of shortterm supplementation of relative selenium excess as sodium selenite and (3) the effects of subcutaneous injection of barium selenate.

\section{Materials and methods}

Experimental design

Experiment 1 comprised a herd of 30 Norwegian Red Cattle dairy cows. The herd was observed for a period of 1 year, starting in 
October 1984. The animals were divided into 2 equal groups based on stage of lactation and age. One group was treated in October with $500 \mathrm{mg}$ selenium as barium selenate (Deposel ${ }^{\mathbb{B}}$ - Rycovet Lt., Glasgow) injected subcutaneously in the neck. The other group served as a control. Whole blood samples were drawn once a month, using heparinized vacutainers and analysed for selenium. The individual intake of concentrates was registered at each visit. The injection sites were inspected every month and were examined post mortem in 2 cows which were slaughtered for other reasons.

During the indoor season (i.e. October-May) the cows were fed home-grown roughage (mainly grass silage), a standardized lowprotein concentrate (Kufôr A, 12.5 \% protein, $0.40 \mathrm{mg} \mathrm{Se} / \mathrm{kg}$ ) and a mineral mixture providing about $1.0 \mathrm{mg} \mathrm{Se} /$ day. During the summer season the animals were on pasture, and they were supplied with a low-protein concentrate according to requirements. No mineral mixture was given during the summer season. The roughage provided about $0.2 \mathrm{mg} \mathrm{Se}$ and about $500 \mathrm{mg}$ Vitamin E per day.

In Experiment 2, a herd consisting of 17 dairy cows, also Norwegian Red, was divided into 3 groups which were given oral supplements of 0,4 and $8 \mathrm{mg}$ selenium per day as sodium selenite, respectively. The supplementation period was 2 months (April and May). The animals were otherwise fed as described for Exp. 1, except that no mineral mixture was given. The estimated daily selenium intake is shown in Table 1.

The cows were put out to pasture at the end of the supplementation period. Blood samples were drawn in the beginning of January, April, June and September, whole blood being collected into heparinized vacutainers. One half of each sample was immediately
Table 1. Estimated average selenium intake ( $\mathrm{mg}$ $\mathrm{Se} /$ day) in selenium supplemented and control animals from January to September. The animals were supplemented with sodium selenite for 2 months starting in April.

\begin{tabular}{lccc}
\hline & \multicolumn{3}{c}{ Group $^{1}$} \\
\cline { 2 - 4 } Month & $\begin{array}{c}\text { Controls } \\
(\mathrm{n}=7)\end{array}$ & $\begin{array}{c}4 \mathrm{mg} \mathrm{Se} / \mathrm{day} \\
(\mathrm{n}=5)\end{array}$ & $\begin{array}{c}8 \mathrm{mg} \mathrm{Se} / \mathrm{day} \\
(\mathrm{n}=5)\end{array}$ \\
\hline January & $1.57^{\mathrm{a}}$ & $1.64^{\mathrm{a}}$ & $0.92^{\mathrm{a}}$ \\
April & $1.06^{\mathrm{a}}$ & $1.70^{\mathrm{a}}$ & $2.52^{\mathrm{a}}$ \\
May & $1.56^{\mathrm{a}}$ & $5.56^{\mathrm{b}}$ & $10.20^{\mathrm{c}}$ \\
June & $1.57^{\mathrm{a}}$ & $5.56^{\mathrm{b}}$ & $10.20^{\mathrm{c}}$ \\
July & $0.60^{\mathrm{a}}$ & $1.56^{\mathrm{b}}$ & $1.96^{\mathrm{b}}$ \\
September & $0.46^{\mathrm{a}}$ & $1.70^{\mathrm{a}}$ & $2.28^{\mathrm{a}}$ \\
\hline
\end{tabular}

${ }^{1}$ Means within rows differ significantly $(\mathrm{p}<0.05)$.

separated and transferred into plastic tubes. The samples were stored at $-20^{\circ} \mathrm{C}$ until analysed for selenium content and glutathione peroxidase (GSH-Px) activity.

\section{Chemical analyses}

Selenium levels in blood, plasma and feed were determined by a hydride generation method (Norheim \& Haugen 1986). GSHPx activity in blood and plasma was determined according to Paglia \& Valentine (1967), using cumen hydro-peroxide as substrate.

\section{Statistical analyses}

The Wilcoxon Two Sample Test was used to assess significance of differences between mean values.

\section{Results}

\section{Experiment 1}

Blood selenium levels in both groups rose during the first 3 months of the experiment. In the experimental group the mean selenium level increased from $0.11 \mu \mathrm{g} / \mathrm{ml}$ to about $0.21 \mu \mathrm{g} / \mathrm{ml}$, and remained at this level 


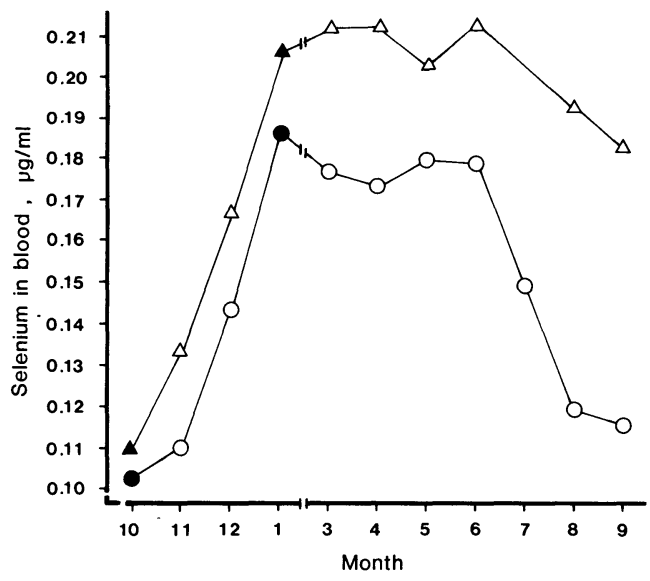

Figure 1. Mean blood selenium levels in animals injected with barium selenate Deposel ${ }^{\mathbf{Q}}$ ) $(\triangle-\mathbf{\Lambda})$ and untreated animals $(\mathrm{O} \longrightarrow$ ) during one year. Open symbols represent significant differences $(p<0.05)$ within month between treated and untreated animals. Treated animals were injected with barium selenate in October. with a slight decrease towards the end of the experiment (Fig. 1).

In the control group, the mean selenium level increased from $0.10 \mu \mathrm{g} / \mathrm{ml}$ to about $0.18 \mu \mathrm{g} / \mathrm{ml}$, and stayed at this level until a marked fall occurred when the cows were turned out onto pasture at the end of May. The corresponding decrease was hardly noticeable in the treated group. From 1 month on, the experimental group had significantly higher levels than the control group ( $p<$ 0.05).

A tennisball-sized swelling appeared at the injection site on the cows. This flattened out after a period of 4 weeks, and remained about the size of a hand throughout the experiment. No signs of pain or inflammation were observed. Histological preparation of granulation tissue of the 2 slaughtered animals revealed a subcutis, rich in lymph vessels and arterioles, infiltrated mainly with

Table 2. Mean levels of selenium in plasma $(\mu \mathrm{g} / \mathrm{ml})$, selenium in blood $(\mu \mathrm{g} / \mathrm{ml})$ and glutathione peroxidase in blood $(\mu \mathrm{kat} / \mathrm{l})$ in selenium supplemented and control animals in the period from April until September. The animals were supplemented with sodium selenite for 2 months starting in April.

\begin{tabular}{lcccccc}
\hline & & \multicolumn{5}{c}{ Month $^{1}$} \\
\cline { 3 - 7 } & $\mathrm{n}$ & April & May & June & July & September \\
\hline Plasma & & & & & & \\
Controls & 7 & $0.041^{\mathrm{a}}$ & $0.044^{\mathrm{a}}$ & $0.054^{\mathrm{a}}$ & $0.035^{\mathrm{a}}$ & $0.037^{\mathrm{a}}$ \\
$4 \mathrm{mg} \mathrm{Se} /$ day & 5 & $0.038^{\mathrm{a}}$ & $0.070^{\mathrm{b}}$ & $0.090^{\mathrm{b}}$ & $0.057^{\mathrm{b}}$ & $0.040^{\mathrm{a}}$ \\
$8 \mathrm{mg} \mathrm{Se} /$ day & 5 & $0.038^{\mathrm{a}}$ & $0.090^{\mathrm{c}}$ & $0.108^{\mathrm{b}}$ & $0.060^{\mathrm{b}}$ & $0.050^{\mathrm{a}}$ \\
Blood & & & & & & \\
Controls & 7 & $0.122^{\mathrm{b}}$ & $0.112^{\mathrm{a}}$ & $0.138^{\mathrm{a}}$ & $0.113^{\mathrm{a}}$ & $0.064^{\mathrm{a}}$ \\
$4 \mathrm{mg} \mathrm{Se} /$ day & 5 & $0.083^{\mathrm{a}}$ & $0.121^{\mathrm{a}}$ & $0.160^{\mathrm{ab}}$ & $0.141^{\mathrm{b}}$ & $0.124^{\mathrm{b}}$ \\
$8 \mathrm{mg} \mathrm{Se} /$ day & 5 & $0.081^{\mathrm{a}}$ & $0.142^{\mathrm{a}}$ & $0.172^{\mathrm{b}}$ & $0.162^{\mathrm{b}}$ & $0.162^{\mathrm{b}}$ \\
Glutathione peroxidase & & & & & & \\
Controls & 7 & $358^{\mathrm{b}}$ & $276^{\mathrm{a}}$ & $417^{\mathrm{a}}$ & $445^{\mathrm{a}}$ & $237^{\mathrm{a}}$ \\
$4 \mathrm{mg} \mathrm{Se} /$ day & 5 & $174^{\mathrm{a}}$ & $251^{\mathrm{a}}$ & $418^{\mathrm{a}}$ & $554^{\mathrm{a}}$ & $492^{\mathrm{ab}}$ \\
$8 \mathrm{mg} \mathrm{Se} /$ day & 5 & $163^{\mathrm{a}}$ & $265^{\mathrm{a}}$ & $444^{\mathrm{a}}$ & $594^{\mathrm{b}}$ & $565^{\mathrm{b}}$ \\
\hline
\end{tabular}

${ }^{1}$ Groups within columns with different superscripts differ significantly $(p<0.05)$. 
mononuclear cells enclosing a granulated mass. The injection site tissues were extracted in boiling hydrochloric acid, and the selenium content was recorded. Of $500 \mathrm{mg}$ injected, $370 \mathrm{mg}$ persisted 5 months later. This corresponds to an approximate selenium release of about $1 \mathrm{mg} /$ day.

\section{Experiment 2}

A significant effect of oral supplement of 4 and $8 \mathrm{mg}$ per day of sodium selenite on plasma selenium levels was registered after 1 month (Table 2).

The effect on blood selenium was slightly delayed compared to that on plasma selenium, and no significant differences were observed before the end of the supplementation period. The GSH-Px activity increased in the 2 supplemented groups, but was not

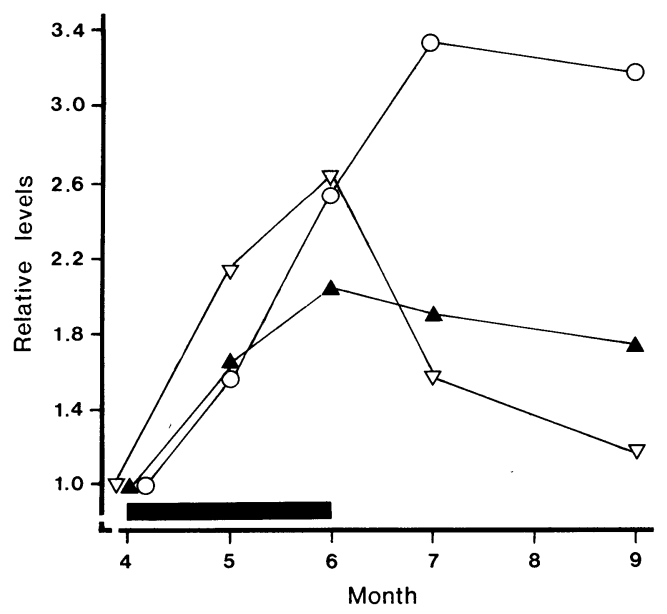

Figure 2. Effect of selenium supplementation on relative mean levels of plasma selenium $(\nabla-\nabla)$, blood selenium ( $\mathbf{\Lambda}$ ) and blood glutathione peroxidase $(\mathrm{O}-\mathrm{O})$. The levels are expressed as a proportion of the values obtained prior to selenium supplementation (i.e. April values equal to 1.0). Animals receiving 4 and $8 \mathrm{mg}$ selenium pr. day $(n=10)$ were grouped together.

$=$ Period of selenium supplementation. significantly different from the control group until 1 month after the supplementation period; the 2 supplemented groups not differing significantly in this respect. Fig. 2 illustrates the relative effect of selenium supplementation upon plasma selenium, blood selenium and GSH-Px activity, respectively.

\section{Discussion}

The control group in Experiment 1 was considered to be quite representative for Norwegian dairy cattle with respect to management and feeding regimens. It would thus appear likely that selenium levels in blood in dairy cows may fluctuate between 0.10 and $0.18 \mu \mathrm{g} / \mathrm{ml}$ throughout the year, with the lowest levels during the grazing season. According to Blood et al. (1983), plasma selenium levels should preferably lie between 0.08 and $0.30 \mu \mathrm{g} \mathrm{Se} / \mathrm{ml}$, corresponding, according to Ropstad et al. (1987), to approximately 0.15 to $0.60 \mu \mathrm{g} \mathrm{Se} / \mathrm{ml}$ whole blood. Carlström et al. (1979) considered the "risk level" for nutritional muscular dystrophy to be $0.035 \mu \mathrm{g} \mathrm{Se} / \mathrm{ml}$ blood, while Jensen \& Agergaard (1981) suggested a "borderline" at $0.05 \mu \mathrm{g} / \mathrm{ml}$. Koller et al. (1983) presented a more differentiated list, in which a blood selenium below $0.05 \mu \mathrm{g} / \mathrm{ml}$ is considered deficient, $0.05-0.075$ low marginal, 0.075-0.100 marginal and above 0.10 $\mu \mathrm{g} \mathrm{Se} / \mathrm{ml}$ adequate. In a given population with the same feeding regimen, individual blood selenium levels will deviate more or less from the mean values. It is therefore advisable to have a safety margin in order to ensure that all animals in the group have an adequate selenium status. Seasonal fluctuations in selenium levels have previously been observed in milk (Gjøen et al. unpublished).

The barium selenate injection had a marked and longlasting effect upon the selenium status in the cows, although the effect was part- 
ly masked by the seasonal fluctuations due to change of diet. The effect of barium selenate injections on blood selenium levels was not as pronounced as in sheep, in which the corresponding doses of selenium resulted in blood levels above $0.30 \mu \mathrm{g} \mathrm{Se} / \mathrm{ml}$ (Øvernes et al. 1985). In a similar experiment with barium selenate injections to heifers, Mallinson et al. (1985) found an increase in plasma selenium from $0.04 \mu \mathrm{g} / \mathrm{ml}$ to 0.08 , corresponding to about 0.06 to $0.15 \mu \mathrm{g}$ $\mathrm{Se} / \mathrm{ml}$ in whole blood (Ropstad et al. 1987). In the present experiment the difference between the control group and the experimental group was less marked. This is probably due to the fact that both groups received a diet which was higher in selenium during the indoor season. The same was also observed when barium selenate was given to sows (Brun \& Øvernes 1986).

It appears that selenium levels in blood do not always show a linear relationship to daily selenium intake. Even when daily intake was nearly doubled as was done in Experiment 2, the effect upon blood selenium and also on GSH-Px was limited. This indicates the existence of a regulatory mechanism. Daily selenium intake is reflected in the plasma levels, but apparently only a part of this is utilized.

Fig. 2 shows that plasma selenium gives an immediate reflection of the daily selenium intake. As stated earlier by several authors, the seleno-enzyme glutathione peroxidase needs to be incorporated into blood cells. Thus, there will be a lag period before it is possible to register a response in enzyme activity. Blood selenium value would seem to be a better parameter for describing the selenium status of the animals than plasma selenium.

In a regular feeding regimen in which compound concentrates enriched with selenium are used, extra selenium supply does not seem to be justified in dairy cattle in Norway. Cows, heifers and beef cattle on pasture, given no or small amounts of supplementory feed, will still have a marginally low selenium status. Depot injection of barium selenate should only be used in herds in which very extensive management systems are used, and in which no other form of supplementation is practical. The problems of local swelling and residues at the injection site also make this route of administration questionable as also stated by $\mathrm{Mal}$ linson et al. (1983).

\section{References}

Blood DC, Radostits OM, Henderson JA: Veterinary Medicine. 6. ed., Baillière, London 1983, p. 1049.

Brun $E$, Øvernes $G$ : Barium selenate as a slowrelease selenium preparation in pigs. Acta vet. scand. 1986, 27, 388-396.

Carlström G, Jönsson G, Pehrson B: An evaluation of selenium status of cattle in Sweden by means of glutathione peroxidase. Swedish J. agric. Res. 1979, 9, 43-46.

Jensen $P$ Thode, Agergaard N: Vurdering af selenstatus i nogle kvægbesætninger ved hjælp af glutathionperoxidasebestemmelser. (Evaluation of selenium status in some cattle herds by analysing gluthathione peroxidase activity). Dansk Vet.-T. 1981, 64, 603-612.

Koller LD, South PS, Exon JH, Whitbeck GA: Selenium deficiency of beef cattle in Idaho and Washington and a practical means of prevention. Cornell Vet. 1983, 73, 323-332.

Mallinson CB, Allen WM, Sansom BF: Barium selenate injections in cattle: Effects on selenium concentrations in plasma and liver and residues at the site of injection. Vet. Rec. 1985, 117, 405-407.

Norheim G, Haugen A: Precise determination of selenium in tissues using automated wet digestion and an automated hydride generator-atomic absorption spectroscopy system. Acta Pharmacol. (Kbh.) 1986, 59, Suppl. 7, 610612. 
Paglia PE, Valentine WN: Studies on the quantitative and qualitative characterisation of erythrocyte glutathione peroxidase. J. Lab. clin. Med. 1967, 70, 158-169.

Ropstad E, Øvernes G, Refsdal AO: Selenium levels in Norwegian dairy herds related to reproductive and health performance. Acta agric. scand. 1987, 37, 397-405.

Øvernes G, Moksnes K, Frøslie A: Barium selenate: a long-acting selenium preparation for subcutaneous injection. Acta vet. scand. 1985, 26, 164-168.

\section{Sammendrag}

Sesongmessig variasjon $i$ selen status hos norske melkekyr og effekten av selentilskudd.

Seleninnholdet i blodet hos melkekyr varierte gjennom året. De høyeste nivåer ble påvist $\mathrm{i}$ innefôringssesongen når kraftfôrbruken var størst.
Gjennomsnittsnivåene av selen i blod økte fra $0.10 \mu \mathrm{g} / \mathrm{ml}$ i oktober til $0.18 \mu \mathrm{g} / \mathrm{ml}$ i januar (15 kyr).

Subcutane injeksjoner av barium selenat $(500 \mathrm{mg}$ selen) ga en signifikant økning av selennivåene i blod. Den behandlede gruppen (15 kyr) hadde gjennomsnittsnivåer omkring $0.21 \mu \mathrm{g} / \mathrm{ml}$ gjennom innefôringsperioden.

Effekten av å gi natrium selenitt peroralt (i $2 \mathrm{mnd}$ ) på plasmaselen, blodselen og glutathion peroksydase aktivitet ble undersøkt. Plasmaselen viste seg å gi et godt bilde av det daglige seleninntak. Maksimal glutation peroksydase aktivitet ble funnet $1 \mathrm{mnd}$ etter at tilførselen av natriumselenitt var opphørt.

Det konkluderes med at under normale fôringsforhold med bruk av kraftfôr tilsatt selen, synes det ikke å være nødvendig å gi ekstra tilskudd til melkekyr.

(Received October 9, 1987).

Reprints may be requested from: Erik Ropstad, Norwegian College of Veterinary Medicine, P. O. Box 8146 Dep, N-0033 Oslo 1, Norway. 